\title{
Co-expression of CD56 and CD30 in lymphomas with primary presentation in the skin: clinicopathologic, immunohistochemical and molecular analyses of seven cases
}

Background: Natural killer and natural killer-like T-cell lymphomas presenting in the skin usually demonstrate aggressive behavior, an angiocentric distribution and a characteristic immunophenotype. In contrast, primary cutaneous CD30+ lymphoproliferative disorders form a heterogeneous spectrum including anaplastic large cell lymphomas, the majority of which display a good prognosis. Lymphomas with coexpression of CD56 and CD30 are extremely rare and the significance of this co-expression is unknown.

Methods: Seven retrospectively identified cases of lymphomas with co-expression of CD56 and CD30 presenting in the skin comprise this study. Immunohistochemistry, in situ hybridization for Epstein-Barr virus and T-cell receptor gene rearrangement studies were performed on paraffin sections.

Results: This subset of cutaneous lymphomas showed a variable clinical course that ranged from resolution without treatment, treatmentfailure and recurrence, to death from disease. Histologic, immunophenotypic and molecular studies were of limited utility in predicting prognosis.

Conclusions: Cutaneous lymphomas co-expressing CD56 and CD30 share many clinicopathologic features with natural killer and natural killer-like T-cell lymphomas or anaplastic large cell lymphomas, two entities with widely disparate clinical behavior. It is important to recognize that these lymphomas may behave more aggressively than primary cutaneous anaplastic large cell lymphomas do. Longer follow-up and further investigations on larger numbers of cases are necessary to fully characterize this rare subset of cutaneous lymphomas.

Natkunam Y, Warnke RA, Haghighi B, Su LD, Le Boit PE, Kim YH, Kohler S. Co-expression of CD56 and CD30 in lymphomas with primary presentation in the skin: clinicopathologic, immunohistochemical and molecular analyses of seven cases.

J Cutan Pathol 2000; 27: 392-399. (C) Munksgaard 2000.

\author{
Yasodha Natkunam ${ }^{1}$, \\ Roger A. Warnke, \\ Bijan Haghighi', Lyndon D. Su ${ }^{2}$, \\ Philip E. Le Boit ${ }^{3,4}$, \\ Youn H. Kim ${ }^{5}$ \\ and Sabine Kohler ${ }^{1,5}$
}

Departments of ${ }^{1}$ Pathology and ${ }^{5}$ Dermatology, Stanford University Medical Center, Stanford, California, USA, 2University of Michigan, Ann Arbor, Michigan, USA, Departments of ${ }^{3}$ Pathology and ${ }^{4}$ Dermatology, University of California, School of Medicine, San Francisco, California, USA

Dr. Yasodha Natkunam, Department of Pathology, Stanford University Medical Center, 300 Pasteur Drive, Stanford, CA, 94305, USA Tel: +16504984617

Fax: +1650725 7409

e-mail: ynatkunam@yahoo.com

Accepted April 6, 2000 
CD56 and CD30 in lymphomas

Cutaneous lymphomas derived from natural killer (NK) or NK-like T-cells are rare among hematolymphoid malignancies presenting in the skin. ${ }^{1-6}$ We have recently reported a series of 12 patients with cutaneous presentation of NK and NK-like T-cell lymphomas that demonstrate a dense superficial and deep dermal lymphoid infiltrate often with an angiocentric growth pattern and a characteristic immunophenotype (CD56+, CD43+, TCR $\gamma-$, CD3-/+, CD20-, CD4-, CD8-). ${ }^{7}$ These lymphomas showed aggressive behavior with a median survival of 15 months from the time of diagnosis. In addition, one of the 12 cases displayed immunoreactivity of the CD56 + atypical large cells for CD30, a member of the nerve growth factor receptor superfamily expressed in activated T and B cells, Hodgkin's disease and anaplastic large cell lymphoma. ${ }^{8-11}$

Cutaneous lymphoproliferative disorders expressing the CD30 antigen form a heterogeneous spectrum which encompasses lymphomatoid papulosis (LyP), some examples of tumor stage mycosis fungoides and several lymphomas with and without anaplastic cytology. ${ }^{11-18}$ Secondary cutaneous anaplastic large cell lymphoma (ALCL) and ALCL arising in mycosis fungoides have a poor prognosis, but primary cutaneous CD30 + ALCLs are associated with a good prognosis with an overall survival rate estimated to be greater than $90 \%$ at 5 years. ${ }^{13-19} \mathrm{NK}$ and NK-like T-cell lymphomas involving the skin usually have a poor prognosis. While the biologic behavior of NK and NK-like T-cell lymphomas presenting in the skin and ALCLs are widely disparate, the initial clinical presentation as well as the histologic features can display significant overlap and may pose considerable diagnostic difficulty. Cutaneous lymphomas that coexpress CD56 and CD30 appear to be rare., ${ }^{4,6,20-25}$ The biological significance of this co-expression is as yet unclear.

We undertook the current study to characterize the clinical, morphologic, immunophenotypic and molecular features of lymphomas presenting in the skin that co-express CD56 and CD30. In addition, we have tested for the presence of the Epstein-Barr virus
$(\mathrm{EBV})$, which is variably associated with both ALCL and NK and NK-like T-cell malignancies. ${ }^{3,4,6,7,20,26}$

\section{Material and methods}

\section{Case selection}

A review of Stanford surgical pathology records from 1995-1998 yielded 52 cases of cutaneous lymphoproliferative disorders with reactivity for CD30. Immunostains for CD56 were performed on these cases as described below. All cases of NK and NKlike T-cell lymphomas had been previously tested for CD30. ${ }^{7}$ In addition, 10 cases of ALCL seen at the University of Michigan (Ann Arbor, MI, USA) were also stained for CD56. From these cases, seven lymphomas that co-express CD56 and CD30 with presentation of disease in the skin were selected. Histologic sections and immunohistochemical studies performed at the time of diagnosis were reviewed. The staging evaluation at the time of diagnosis included complete blood count and chemistries, chest X-ray or chest computed tomography (CT), CT of abdomen and pelvis, and bone marrow biopsy.

\section{Histologic features}

Hematoxylin and eosin $(\mathrm{H} \& \mathrm{E})$-stained sections were reviewed to assess histologic parameters including epidermotropism, angiocentrism, angiodestruction, fat involvement, ulceration, necrosis, anaplasia, prominence of nucleoli, and karyorrhexis. These parameters were categorized as absent/inconspicuous $(-)$, mild $(+)$, or prominent $(++)$.

\section{Immunohistochemistry}

Primary antibodies were directed against CD3, CD4，CD8，CD20，CD30，CD43，CD56, CD68, TIA1, MPO (myeloperoxidase) and Ki-67 (summarized in Table 1). Serial sections of 4 microns were cut and deparaffinized in xylene and hydrated in a graded series of alcohol. The sections were then pretreated by a microwave procedure in citric acid

Table 1. Antibody reagents used for immunohistochemical studies

\begin{tabular}{llll}
\hline Antigen & Antibody/clone & Source & Cell reactivity \\
\hline CD3 & Polyclonal CD3 & Dako, Carpinteria, CA, USA & T cells \\
CD4 & IF6 & Novocastra, UK & T helper/inducer, monocytes \\
CD8 & C8/144B & Dako & T cytotoxic/suppressor \\
CD20 & L26 & Dako & B cells \\
CD30 & BerH2 & Dako & Activated T and B cells \\
CD43 & Leu22 & Becton Dickinson, San Jose, CA, USA & T cells, other \\
CD56 & $123 C 3$ & Monosan, Uden, The Netherlands & NK, NK-like T cells \\
CD68 & KP1 & Dako & Myeloid, macrophage \\
TIA-1 & NS/1-AG4 & Coulter, Hialeah, FL, USA & NK, T cytotoxic \\
MP0 & Myeloperoxidase & Dako & Myeloid lineage \\
Ki-67 & MIB-1 & Immunotech, Cedex, France & Proliferating cells \\
\hline
\end{tabular}


buffer $(10 \mathrm{mM}, \mathrm{pH} 6.0)$ for $10 \mathrm{~min}$ prior to staining for CD3, CD8, CD20, CD30, CD43, CD56, CD68, TIA-1, and Ki-67. For CD4, pretreatment was performed in EDTA (1mM, pH 8.0). Endogenous peroxidase was blocked by preincubation with $1 \%$ hydrogen peroxide in phosphate-buffered saline. Detection for CD3, CD20, CD30, CD43, CD68, MPO and TIA-1 was performed on an automated staining machine (Ventana Medical Systems Inc., Tucson, AZ, USA). Detection for CD56, Ki-67, and CD4 was performed using a modified biotinstreptavidin method. ${ }^{27}$

\section{In situ hybridization for EBV}

EBV RNA in situ hybridization studies were performed using a 30-base oligonucleotide probe complementary to a portion of the EBER1 gene as previously described. ${ }^{28}$ Five-micron thick paraffin sections were deparaffinized, rehydrated, predigested with proteinase $\mathrm{K}$ and hybridized overnight at a concentration of $0.25 \mathrm{ng} / \mathrm{ml}$ of biotinylated probe. Detection was accomplished using avidin-alkaline phosphatase conjugate. Appropriate positive and negative controls were performed.

Heteroduplex analysis of T-cell receptor gamma (TCR- $\gamma$ ) gene rearrangement

Amplification and heteroduplex analysis for TCR- $\gamma$ gene rearrangement was performed as previously described. ${ }^{29}$ Consensus primers for the TCR V-J junction were used to amplify genomic DNA isolated from paraffin-embedded tissue as described. ${ }^{29}$ The amplified products were then analyzed on a Mutation Detection Enhancement (MDE) gel (FMC Bioproducts, Rocklands, ME, USA) for $12 \mathrm{~h}$ at $90 \mathrm{~V}$ in tris-borateEDTA buffer.

\section{Results}

Clinical features

The clinical findings are summarized in Table 2. The patients included four men and three women ranging in age from 19 to 79 years (mean age 46.7 years). All patients presented with initial manifestation of lymphoma in the skin. Six patients had disease confined to the skin as assessed by a staging workup. One patient (case 6) developed involvement of the soft palate 6 months after the initial skin diagnosis. None of the patients had lymph node or peripheral blood involvement. Four of the seven patients had multiple skin lesions at presentation, while three had disease limited to a single cutaneous lesion. The initial cutaneous lesions were found on the upper and/or lower extremities in four patients, confined to the hip in one patient and involved the trunk in addition to the extremities in the remaining two patients. None of the patients had significant past medical histories, evidence of immunosuppression or prior malignancies.

The disease course was variable in the seven patients (Table 2). Four patients are in clinical remission without relapse (cases 1, 2, 3, and 5), one patient is in remission with history of relapse (case 4), one patient is alive with recurrent disease (case 7), and one patient died of disease (case 6). Three patients were initially treated with chemotherapy (case 1,2 and 4) of whom two, in addition, received local (case 1) or total skin radiation (case 2). Patient 2 received an autologous bone marrow transplantation after only partial response to initial therapy, and is in clinical remission at the time of completion of this study. Two patients were treated initially with local radiation alone (cases 3 and 6), one of whom remains in clinical remission (case 3), while the other patient had recurrence involving the trunk, extremities and the soft pal-

Table 2. Clinical summary

\begin{tabular}{|c|c|c|c|c|c|}
\hline Case & Age/sex & Presenting signs and symptoms & $\begin{array}{l}\text { Documented sites } \\
\text { of involvement }\end{array}$ & Treatment & $\begin{array}{c}\text { Outcome } \\
(\mathrm{M}=\text { months })\end{array}$ \\
\hline $\begin{array}{l}1 \\
2\end{array}$ & $\begin{array}{l}43 / \mathrm{F} \\
19 / \mathrm{M}\end{array}$ & $\begin{array}{l}\text { Single polypoid nodule on left hip } \\
\text { Tumor nodules on abdomen, trunk and } \\
\text { upper extremity; recurrence on trunk and } \\
\text { extremities }\end{array}$ & $\begin{array}{l}\text { Skin } \\
\text { Skin }\end{array}$ & $\begin{array}{l}\text { Chemotherapy and local radiation } \\
\text { Chemotherapy and total skin radiation } \\
\text { with autologous bone marrow transplant }\end{array}$ & $\begin{array}{l}\text { AlR, } 9 \mathrm{M} \\
\text { AlR, } 20 \mathrm{M}\end{array}$ \\
\hline 3 & $79 / F$ & $\begin{array}{l}\text { Tumor nodules on calf and ankle; recurrence } \\
\text { on thigh }\end{array}$ & Skin & Local radiation & AlR, $18 \mathrm{M}$ \\
\hline 4 & $52 / \mathrm{M}$ & $\begin{array}{l}\text { Single multinodular plaque on upper } \\
\text { extremity; recurrence, same area }\end{array}$ & Skin & Chemotherapy; local radiation for recurrence & AlR, $30 \mathrm{M}$ \\
\hline 5 & $50 / F$ & Single nodule on great toe & Skin & Observation & AIR, $24 \mathrm{M}$ \\
\hline 6 & $37 / \mathrm{M}$ & $\begin{array}{l}\text { Ulcerating nodules on extremities, trunk, } \\
\text { and scrotum; recurrence on trunk, lower } \\
\text { extremity, and soft palate }\end{array}$ & Skin, soft palate & $\begin{array}{l}\text { Local radiation; Chemotherapy for } \\
\text { recurrence }\end{array}$ & $\mathrm{DOD}, 15 \mathrm{M}$ \\
\hline 7 & $47 / M$ & $\begin{array}{l}\text { Multiple tumor nodules on posterior } \\
\text { right leg }\end{array}$ & Skin & $\begin{array}{l}\text { Observation; recurrent lesions are } \\
\text { self-resolving }\end{array}$ & AWD, $15 \mathrm{M}$ \\
\hline
\end{tabular}

$A I R=$ alive in remission; $A W D=$ alive with disease; $D O D=$ died of disease. 


\begin{tabular}{|c|c|c|c|c|c|c|c|}
\hline Parameter & 1 & 2 & 3 & 4 & 5 & 6 & 7 \\
\hline Epidermotropism & + & + & + & $N A^{*}$ & ++ & 0 & 0 \\
\hline Angiocentric infiltrate & + & ++ & ++ & ++ & ++ & ++ & ++ \\
\hline Panniculitis-like infiltrate & 0 & $N A^{\star \star}$ & ++ & $N A^{\star *}$ & + & + & + \\
\hline Ulceration & + & + & 0 & + & 0 & ++ & 0 \\
\hline Necrosis & 0 & 0 & + & 0 & 0 & + & 0 \\
\hline Anaplasia & ++ & + & + & ++ & + & ++ & + \\
\hline Karyorrhexis & ++ & + & ++ & ++ & + & ++ & ++ \\
\hline
\end{tabular}

All histologic parameters were scored as follows:

Absent/inconspicuous $(-)$, mild $(+)$, prominent $(++)$, or not assessed (NA).

* no epidermis available for assessment of epidermotropism.

** depth of biopsy insufficient for evaluation of panniculitis-like infiltrate.

ate requiring chemotherapy and died of disease (case 6). Two patients received no treatment at all (cases 5 and 7). Patient 5 who presented with a single nodule on the toe, underwent spontaneous resolution and is without disease two years after diagnosis. The other patient continues to have recurrent self-resolving nodules (case 7).

\section{Histologic features}

The histologic findings are summarized in Table 3. The skin biopsies from all seven patients exhibited dense lymphoid infiltrates with atypical cytologic features. These infiltrates had a "column-like" architecture exemplified by extension of the infiltrates from the superficial to the deep dermis with prominent perivascular and periappendageal involvement. An increased density of neoplastic cells was present deep within the dermis (Fig. 1A).
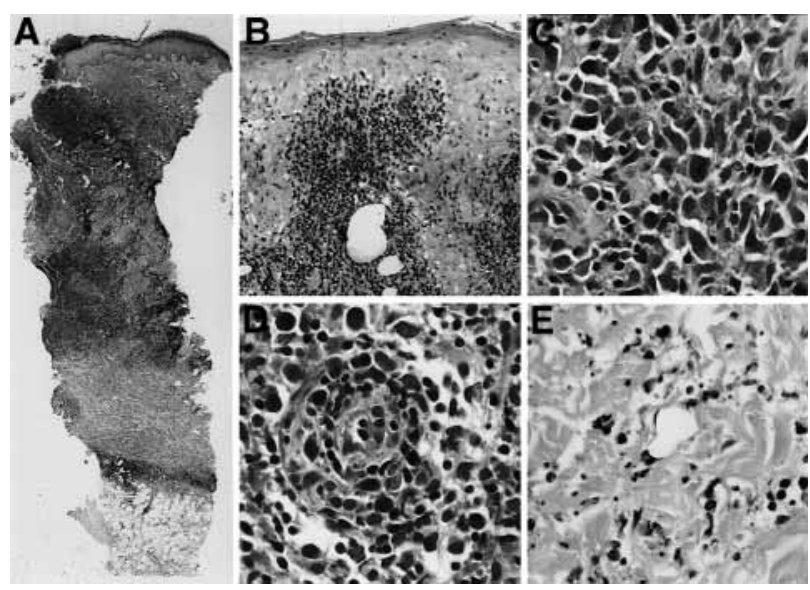

Fig. 1. Skin biopsy. A) Atypical lymphoid infiltrate exhibiting column-like architecture and a dense infiltrate in the deep dermis (H\& E, $\times 60)$. B) Neoplastic cells showing mild epidermotropism (H\&E, $\times 150$ ). C) Large neoplastic cells with pleomorphic nuclear contours admixed with small reactive lymphocytes with condensed chromatin $(\mathrm{H} \& \mathrm{E}, \times 600)$. D) Neoplastic cells showing angiodestruction $(\mathrm{H} \& \mathrm{E}, \times 600)$. E) Focus of necrosis within the dermis $(\mathrm{H} \& \mathrm{E}, \times 600)$.
Epidermotropism was a minor component in four of six cases, although in one case a prominent epidermal infiltrate was seen (case 5). Angiocentric infiltrates were observed in all cases, while angiodestructive lesions were present in five cases (Fig. 1B). Destruction of adnexal structures was not observed. Involvement of the fat (panniculitis-like infiltration) was a prominent finding in four of five cases where the depth of the biopsy was adequate for assessment of this parameter. Ulceration was present in three cases (2, 4 and 6), while areas of necrosis within the dermis were observed in two biopsies (cases 3 and 6).

The cytology of the lymphoid infiltrates revealed a mixture of cell sizes ranging from small to medium to large. In all biopsies, the medium- to large-sized cells displayed nuclear pleomorphism; however, anaplastic cytology was prominent in three cases $(1,4$, and 6 ; Fig. 1C). Marked karyorrhexis was present in five of seven cases. Scattered small lymphoid cells and histiocytes were admixed with the large atypical cells, most likely representing a host response. Occasional histiocytes and eosinophils were also present intermingled with the atypical lymphoid cells.

\section{Immunohistochemical studies}

Results from immunohistochemical studies are summarized in Table 4. Cutaneous biopsies from all seven patients revealed immunoreactivity of the large atypical cells for CD56 and CD30 (Fig. 2A, B), as this was a criterion for selection for the study. Staining for both markers was predominantly localized to the cell membranes. The number of atypical cells stained in each case was variable, as indicated in Table 4. Six of the seven cases displayed immunoreactivity with polyclonal anti-CD3, which recognizes the epsilon $(\varepsilon)$ subunit of the T-cell receptor-CD3 signal transduction complex (Fig. 2C). All cases showed strong immunoreactivity for CD43. The atypical cells from all seven cases lacked staining for the T-helper/inducer marker, CD4, T-cytotoxic/suppresser marker, CD8, the B-cell marker CD20, myeloperoxidase (MPO) 


\section{Natkunam et al.}

Table 4. Immunohistochemistry, in situ hybridization and molecular analyses

\begin{tabular}{lcccccccc}
\hline Antigen & 1 & 2 & 3 & 4 & 5 & 6 & 7 & Total \\
\hline CD56 & $+20 \% *$ & $+>50 \%$ & $+>80 \%$ & $+>80 \%$ & $+>80 \%>$ & $+>80 \%$ & $+10 \%$ & $7 / 7(100 \%)$ \\
CD30 & $+>90 \%$ & $+>50 \%$ & $+>80 \%$ & $+>80 \%$ & $+20 \%$ & $+30 \%$ & $+>80 \%$ & $7 / 7(100 \%)$ \\
CD3 & + & + & + & + & + & - & + & - \\
CD4 & - & - & - & - & - & - & - & $0 / 7(86 \%)$ \\
CD8 & - & - & - & - & - & - & - & $0 / 7(0 \%)$ \\
CD20 & - & - & - & - & - & - & - & $0 / 7(0 \%)$ \\
CD43 & + & + & + & + & + & + & - & $7 / 7(100 \%)$ \\
CD68 & - & - & - & - & - & - & - & $0 / 7(0 \%)$ \\
TIA1 & + & - & + & - & + & - & - & $3 / 7(42 \%)$ \\
MP0 & - & - & - & - & - & - & - & $0 / 7(0 \%)$ \\
Ki-67 & $90 \%$ & $-30 \%$ & $90 \%$ & $30 \%$ & $60 \%$ & $30 \%$ & $80 \%$ & $30-90 \%$ \\
EBV in situ hybridization & - & - & + & + & - & + & - & $3 / 7(42 \%)$ \\
PCR analysis for TCR & + & + & - & - & - & - & + & $3 / 7(42 \%)$ \\
\hline
\end{tabular}

*Percent of lesional cells positive for CD56 and CD30.

and the myeloid/macrophage-associated antigen, CD68. A subset of small lymphoid cells showed positive staining for CD8 (Fig. 2D). These cells presumably correspond to reactive $\mathrm{T}$ cells. Three of seven cases showed staining for TIA-1 (Fig. 2E). All seven cases showed moderate to high proliferation rates $(30-90 \%)$ as assessed by $\mathrm{Ki}-67$, a nuclear antigen expressed in proliferating cells (Fig. 2F), corroborating the histologic findings of often brisk mitotic activity seen on hematoxylin and eosin (H\&E)-stained sections.

\section{In situ hybridization for EBV}

Results of in situ hybridization studies are summarized in Table 4. Using the EBER1 oligonucleotide probe, three of seven cases exhibited nuclear localization of EBV mRNA within atypical cells constituting the cutaneous lymphoid infiltrates.

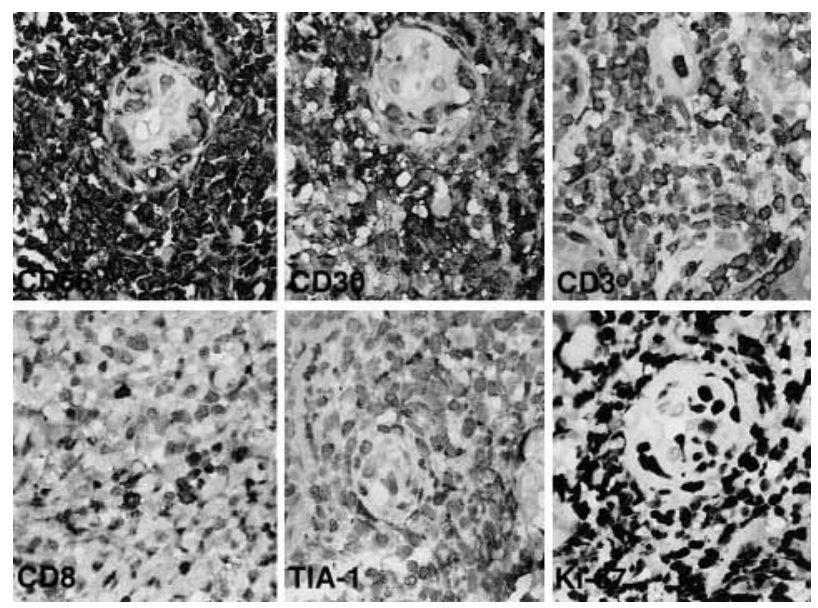

Fig. 2. Immunohistochemical studies showing reactivity for CD56, CD30, CD3, CD8, TIA-1 and Ki-67, by the neoplastic cells (H\& $\mathrm{E}, \times 600)$.

\section{Heteroduplex analyses of TCR- $\gamma$ gene rearrangement}

Results of TCR- $\gamma$ rearrangement studies are summarized in Table 4. Three cases showed strong clonal bands indicating the presence of TCR- $\gamma$ gene rearrangements. As T-cell receptor gene rearrangements would not be expected in lymphomas derived from natural killer cells, these three lymphomas are most likely derived from $\mathrm{T}$ cells.

\section{Discussion}

The seven patients described in this study are unusual in that they had lymphomas exhibiting a rare CD56+, CD30+ immunophenotype with the initial manifestation of their disease in the skin. There are a few reports of lymphomas with co-expression of GD56 and CD30.4,6,7,20,21,23-25 All of these reported cases of lymphomas were localized to extranodal sites, of which three presented with lymphoma in the skin. ${ }^{7,25}$ These investigations suggest that co-expression of CD56 and CD30, especially in lymphomas with primary presentation in the skin, is exceedingly rare.

The patients in the current study showed a wide age distribution and no particular sex predilection. The most common sites of involvement were the extremities and trunk, similar to previous reports of cutaneous NK and NK-like T-cell lymphomas, ${ }^{3,4,7}$ and ALCL, although ALCL also commonly involves the scalp and face. ${ }^{13,17}$ Similarly, single or multiple nodules, often ulcerated were typical in these patients, as reported in both diseases., $3,4,7,13,17$ Nuclear pleomorphism has been described in both NK and NKlike T-cell lymphomas and ALCL; however, prominent anaplastic cytology, a feature of three of the cases in this study, is particularly distinctive of ALCL. ${ }^{1-3,6,7,11,13,17,30}$ While two of the patients in our study who displayed anaplastic cytology (cases 4 and 6) exhibited an aggressive clinical course, another 
patient whose biopsy displayed marked anaplasia (case 1), did not. Angiocentric distribution of the atypical infiltrate, present in all cases in this study, is commonly associated with $\mathrm{NK}$ and NK-like T-cell lymphomas ALCL. ${ }^{1-3,6,7,30}$ This pattern of infiltration is less frequent in ALCL. ${ }^{17}$ Infiltration and destruction of vessel walls, apparent in five of seven cases in this study is most frequent in NK and NK-like T-cell lymphomas. ${ }^{1-3,6,7,30}$ Thus, the histologic features of these seven cases show significant overlap with those of NK and NK-like T-cell lymphomas and ALCL.

By definition, all seven cases in our study showed immunoreactivity for CD56 and CD30 in the large atypical cells, although variable numbers of cells exhibited positive staining for each of these markers. The typical immunophenotype was as follows: CD56+, $\mathrm{CD} 30+, \mathrm{CD} 43+, \mathrm{CD} 3(\varepsilon)+/-, \mathrm{TIA} 1-/$ $+, \mathrm{CD} 4-, \mathrm{CD} 8-, \mathrm{CD} 20-, \mathrm{CD} 68-, \mathrm{MPO}-. \mathrm{Im}-$ munoreactivity for TIA-1, a cytoplasmic granule-associated protein found in cytotoxic $\mathrm{T}$ cells and NK cells, was observed in three of seven cases $(42 \%)$ in our study. Other investigators have reported TIA-1 expression in $63-92 \%$ of ALCL and NK and NK-like T-cell lymphomas. ${ }^{17,25,31-33}$ This immunophenotype shows significant overlap between the immunophenotypic profiles reported for NK and NK-like T-cell lymphomas and ALCL.

A very high correlation between NK and NK-like T-cell lymphomas, especially of the nasal-type, and EBV has been reported by some authors, ${ }^{3,5,26,34}$ while an inconsistent association has been reported by others. ${ }^{7,26}$ Occasional cases of ALCL are also known to harbor EBV mRNA, ${ }^{35-38}$ although a vast majority of ALCL cases lack EBV. ${ }^{17}$ In the current study, EBV mRNA was detected in three of seven cases $(42 \%)$, utilizing in situ hybridization studies for EBER 1 mRNA. There was no distinct correlation between EBV mRNA expression and adverse clinical outcome in our study.

Immunoreactivity for cytoplasmic CD3 (CD3 epsilon), a component of the TCR signal transduction complex, was detected in six cases, while clonal TCR$\gamma$ rearrangement confirming a T-cell lineage was detected in only three cases. Thus, four of the cases in this study may be of true NK-cell derivation, as clonal rearrangement of TCR- $\gamma$ is a feature of T-cell lineage while CD3 $\varepsilon$ can be expressed by cells of pure NK lineage. Immunohistochemical and molecular analyses have demonstrated clonality in approximately $91 \%$ of CD30 - ALCL. ${ }^{17,32,33}$ Thus, a minority of cases of ALCL may not exhibit detectable TCR gene rearrangements. The absence of TCR- $\gamma$ rearrangements in four cases in our study does not differentiate between a T-cell or an NK-cell derivation for these lymphomas. A bipotential progenitor cell giving rise to true NK lymphomas as well as NK-like T-cell lymphomas, ${ }^{39-41}$ may be a likely derivation for lym- phomas co-expressing CD56 and CD30, especially for those with an adverse clinical course. However, an activated CD30+ T-cell with aberrant expression of CD56, ${ }^{21}$ may also be responsible for lymphomagenesis. While determining the cell of origin may be important for understanding the biological behavior of these lymphomas and for classification, it is not clear whether this is pertinent for diagnosis or management.

Cutaneous CD56+ NK and NK-like T-cell lymphomas are highly aggressive and are often accompanied by treatment failure, multiple recurrences, dissemination to other sites and poor clinical outcome. ${ }^{1-4,6,7,30}$ In contrast, CD30+ALCLs that are limited to the skin at presentation as solitary or multiple nodules are associated with an excellent prognosis. Spontaneous regression with or without relapse is observed in CD30 + ALCLs and the five year overall survival rate is estimated to be $90 \% .^{11,14-19}$ The disease course of patients in our study was variable, and ranged from spontaneous resolution in one patient, clinical remission post-treatment in four patients, alive with recurrent disease in one patient, and death from disease with involvement of another extranodal site (soft palate) in one patient. While one of the patients (cases 6) had disease that behaved in a more aggressive manner than primary cutaneous CD30+ ALCL, the other six patients displayed a clinical course considered typical for primary cutaneous CD30+ ALCL. It is unclear whether the less aggressive clinical course in these latter six patients is due to the biological behavior associated with coexpression of CD56 and CD30 or to the limited involvement of their disease mostly in one anatomical location, or both. The rarity of primary cutaneous lymphomas with co-expression of CD56 and CD30, together with the relatively short follow-up period of patients in our study, make assessment of prognosis difficult. Further clinicopathologic investigations on larger numbers of patients are needed for an accurate and meaningful evaluation of prognosis in these lymphomas.

Our results indicate that cutaneous lymphomas that co-express CD56 and CD30 share significant clinicopathologic overlap with cutaneous ALCL and NK and NK-like T-cell lymphomas. Immunophenotypic studies are imperative in distinguishing these lymphomas from mycosis fungoides, lymphomatoid papulosis, peripheral T-cell lymphoma, subcutaneous panniculitic T-cell lymphoma, ${ }^{42}$ myeloid/natural killer cell precursor lymphoma/leukemia, ${ }^{43-45} \mathrm{CD} 4+$ CD56 + cutaneous neoplasm, ${ }^{46}$ and cutaneous B-cell lymphoma, which are considerations in the histologic differential diagnosis. Thus, CD56 and CD30 are important markers in a panel selected for immunohistologic studies when evaluating a dense deep dermal atypical lymphoid infiltrate, and both antigens should 


\section{Natkunam et al.}

be assessed together. Predictions of prognosis based on our data are difficult. Further investigations are needed to characterize the mechanism of how a neural cell adhesion molecule such as CD56 and a growth factor receptor-like molecule such as CD30 may orchestrate the pathogenesis and progression of these rare lymphomas.

\section{References}

1. Ansai S, Maeda K, Yamakawa M, et al. CD56-positive (nasaltype T/NK cell) lymphoma arising on the skin. Report of two cases and review of the literature. J Cutan Pathol 1997; 24: 468.

2. Chan JK, Ng CS, Ngan KC, Hui PK, Lo ST, Lau WH. Angiocentric T-cell lymphoma of the skin. An aggressive lymphoma distinct from mycosis fungoides. Am J Surg Pathol 1988; 12: 861.

3. Chan JK, Sin VC, Wong KF, et al. Nonnasal lymphoma expressing the natural killer cell marker CD56: a clinicopathologic study of 49 cases of an uncommon aggressive neoplasm. Blood 1997; 89: 4501.

4. Nakamura S, Suchi T, Koshikawa T, et al. Clinicopathologic study of CD56 (NCAM)-positive angiocentric lymphoma occurring in sites other than the upper and lower respiratory tract. Am J Surg Pathol 1995; 19: 284.

5. Jaffe ES, Chan JK, Su IJ, et al. Report of the Workshop on nasal and related extranodal angiocentric $\mathrm{T} /$ natural killer cell lymphomas. Definitions, differential diagnosis, and epidemiology. Am J Surg Pathol 1996; 20: 103.

6. Wong KF, Chan JK, Ng CS, Lee KC, Tsang WY, Cheung MM. CD56 (NKH1)-positive hematolymphoid malignancies: an aggressive neoplasm featuring frequent cutaneous/mucosal involvement, cytoplasmic azurophilic granules, and angiocentricity. Hum Pathol 1992; 23: 798.

7. Natkunam Y, Smoller BR, Zehnder JL, Dorfman RF, Warnke RA. Aggressive cutaneous NK and NK-like T-cell lymphomas: clinicopathologic, immunohistochemical, and molecular analyses of 12 cases. Am J Surg Pathol 1999; 23: 571.

8. Stein H, Mason DY, Gerdes J, et al. The expression of the Hodgkin's disease associated antigen $\mathrm{Ki}-1$ in reactive and neoplastic lymphoid tissue: evidence that Reed-Sternberg cells and histiocytic malignancies are derived from activated lymphoid cells. Blood 1985; 66: 848.

9. Piris M, Brown DC, Gatter KC, Mason DY. CD30 expression in non-Hodgkin's lymphoma. Histopathology 1990; 17: 211.

10. Durkop H, Latza U, Hummel M, Eitelbach F, Seed B, Stein $\mathrm{H}$. Molecular cloning and expression of a new member of the nerve growth factor receptor family that is characteristic for Hodgkin's disease. Cell 1992; 68: 421.

11. LeBoit PE. Hodgkin's disease, anaplastic large cell lymphoma, and lymphomatoid papulosis. Another scalpel blunted. Am J Clin Pathol 1995; 104: 3.

12. Marzano AV, Alessi E, Berti E. CD30-positive multilobated peripheral T-cell lymphoma primarily involving the subcutaneous tissue. Am J Dermatopathol 1997; 19: 284.

13. LeBoit PE. Lymphomatoid papulosis and cutaneous CD30+ lymphoma. Am J Dermatopathol 1996; 18: 221.

14. Vergier B, Beylot-Barry M, Pulford K, et al. Statistical evaluation of diagnostic and prognostic features of CD30+ cutaneous lymphoproliferative disorders: a clinicopathologic study of 65 cases. Am J Surg Pathol 1998; 22: 1192.
15. Kaudewitz P, Stein H, Dallenbach F, et al. Primary and secondary cutaneous $\mathrm{Ki}-1+(\mathrm{CD} 30+)$ anaplastic large cell lymphomas. Morphologic, immunohistologic, and clinical-characteristics. Am J Pathol 1989; 135: 359.

16. Beljaards RC, Meijer CJ, Scheffer E, et al. Prognostic significance of CD30 (Ki-1/Ber-H2) expression in primary cutaneous large-cell lymphomas of T-cell origin. A clinicopathologic and immunohistochemical study in 20 patients. Am J Pathol 1989; 135: 1169.

17. Chan JKC. Anaplastic large cell lymphoma: Redefining its morphologic spectrum and importance of recognititon of the ALK-positive subset. Adv Anatomic Pathol 1998; 5: 281.

18. Paulli M, Berti E, Rosso R, et al. CD30/Ki-1-positive lymphoproliferative disorders of the skin-clinicopathologic correlation and statistical analysis of 86 cases: a multicentric study from the European Organization for Research and Treatment of Cancer Cutaneous Lymphoma Project Group. J Clin Oncol 1995; 13: 1343.

19. Beljaards RC, Kaudewitz P, Berti E, et al. Primary cutaneous CD30-positive large cell lymphoma: definition of a new type of cutaneous lymphoma with a favorable prognosis. A European Multicenter Study of 47 patients. Cancer 1993; 71: 2097.

20. van Gorp J, Weiping L, Jacobse K, et al. Epstein-Barr virus in nasal T-cell lymphomas (polymorphic reticulosis/midline malignant reticulosis) in western China. J Pathol 1994; 173: 81.

21. Paulli M, Boveri E, Rosso R, et al. CD56/neural cell adhesion molecule expression in primary extranodal $\mathrm{Ki}-1 / \mathrm{CD} 30+$ lymphoma. Report of a pediatric case with simultaneous cutaneous and bone localizations. Am J Dermatopathol 1997; 19: 384 .

22. Akamatsu M, Takeshita M, Ohshima K, Kikuchi M, Suzumiya J. Analysis of adhesion molecules in $\mathrm{Ki}-1$ anaplastic largecell lymphoma. Virchows Arch 1994; 425: 33.

23. Chan JK, Tsang WY, Hui PK, et al. T- and T/natural killercell lymphomas of the salivary gland: a clinicopathologic, immunohistochemical and molecular study of six cases. Hum Pathol 1997; 28: 238.

24. Tsutsumi Y, Tang X, Yamada T. Epstein-Barr virus (EBV)induced CD30+ natural killer cell-type malignancy resembling malignant histiocytosis: malignant transformation in chronic active EBV infection associating hypogammaglobulinemia. Pathol Int 1997; 47: 384.

25. Felgar RE, Salhany KE, Macon WR, Pietra GG, Kinney MC. The expression of TIA-1+ cytolytic-type granules and other cytolytic lymphocyte-associated markers in CD30+ anaplastic large cell lymphomas (ALCL): correlation with morphology, immunophenotype, ultrastructure, and clinical features. Hum Pathol 1999; 30: 228.

26. Kobashi Y, Nakamura S, Sasajima Y, et al. Inconsistent association of Epstein-Barr virus with CD56 (NCAM)-positive angiocentric lymphoma occuring in sites other than the upper and lower respiratory tract. Histopathology 1996; 28: 111.

27. Bindl JM, Warnke RA. Advantages of detecting monoclonal antibody binding to tissue sections with biotin and avidin reagents in Coplin jars. Am J Clin Pathol 1986; 85: 490.

28. van de Rijn M, Cleary ML, Variakojis D, Warnke RA, Chang PP, Kamel OW. Epstein-Barr virus clonality in lymphomas occurring in patients with rheumatoid arthritis. Arthritis Rheum 1996; 39: 638.

29. Kohler S, Jones C, Warnke R, Zehnder J. Heteroduplex analysis of T-cell receptor gamma gene rearrangement in par- 
affin embedded skin biopsies. Am J Dermatopathol 2000; in press.

30. Takeshita M, Akamatsu M, Ohshima K, et al. Angiocentric immunoproliferative lesions of the skin show lobular panniculitis and are mainly disorders of large granular lymphocytes. Hum Pathol 1995; 26: 1321.

31. Felgar RE, Macon WR, Kinney MC, Roberts S, Pasha T, Salhany KE. TIA-1 expression in lymphoid neoplasms. Identification of subsets with cytotoxic $\mathrm{T}$ lymphocyte or natural killer cell differentiation. Am J Pathol 1997; 150: 1893.

32. Foss HD, Anagnostopoulos I, Araujo I, et al. Anaplastic largecell lymphomas of T-cell and null-cell phenotype express cytotoxic molecules. Blood 1996; 88: 4005.

33. Krenacs L, Wellmann A, Sorbara L, et al. Cytotoxic cell antigen expression in anaplastic large cell lymphomas of $\mathrm{T}$ - and null-cell type and Hodgkin's disease: evidence for distinct cellular origin. Blood 1997; 89: 980.

34. Tsang WY, Chan JK, Yip TT, et al. In situ localization of Epstein-Barr virus encoded RNA in non-nasal/nasopharyngeal CD56-positive and CD56-negative T-cell lymphomas. Hum Pathol 1994; 25: 758.

35. Kanavaros P, Jiwa NM, de Bruin PC, et al. High incidence of EBV genome in CD30-positive non-Hodgkin's lymphomas. J Pathol 1992; 168: 307.

36. Herbst H, Sander C, Tronnier M, Kutzner H, Hugel H, Kaudewitz P. Absence of anaplastic lymphoma kinase (ALK) and Epstein-Barr virus gene products in primary cutaneous anaplastic large cell lymphoma and lymphomatoid papulosis. Br J Dermatol 1997; 137: 680.

37. Lopategui JR, Gaffey MJ, Chan JK, et al. Infrequent association of Epstein-Barr virus with CD30-positive anaplastic large cell lymphomas from American and Asian patients. Am J Surg Pathol 1995; 19: 42.
38. Nakamura S, Shiota M, Nakagawa A, et al. Anaplastic large cell lymphoma: a distinct molecular pathologic entity: a reappraisal with special reference to p80(NPM/ALK) expression. Am J Surg Pathol 1997; 21: 1420.

39. Ino T, Tsuzuki M, Okamoto M, Shamoto M, Hirano M. Acute leukemia with the phenotype of a natural killer/T cell bipotential precursor. Ann Hematol 1999; 78: 43.

40. Lanier LL, Chang C, Spits H, Phillips JH. Expression of cytoplasmic CD3 epsilon proteins in activated human adult natural killer (NK) cells and CD3 gamma, delta, epsilon complexes in fetal NK cells. Implications for the relationship of NK and T lymphocytes. J Immunol 1992; 149: 1876.

41. Spits H, Lanier LL, Phillips JH. Development of human T and natural killer cells. Blood 1995; 85: 2654.

42. Kumar S, Krenacs L, Medeiros J, et al. Subcutaneous panniculitic T-cell lymphoma is a tumor of cytotoxic T lymphocytes. Hum Pathol 1998; 29: 397.

43. Scott AA, Head DR, Kopecky KJ, et al. HLA-DR -, CD33+, CD56+, CD16 - myeloid/natural killer cell acute leukemia: a previously unrecognized form of acute leukemia potentially misdiagnosed as French-American-British acute myeloid leukemia-M3. Blood 1994; 84: 244.

44. Suzuki R, Yamamoto K, Seto M, et al. CD7+ and CD56+ myeloid/natural killer cell precursor acute leukemia: a distinct hematolymphoid disease entity. Blood 1997; 90: 2417.

45. Kuwabara H, Nagai M, Yamaoka G, Ohnishi H, Kawakami K. Specific skin manifestations in CD56-positive acute myeloid leukemia. J Cutan Pathol 1999; 26: 1.

46. Petrella T, Dalac S, Maynadie M, et al. CD4+ CD56+ cutaneous neoplasms: a distinct hematological entity? Am J Surg Pathol 1999; 23: 137. 